\title{
Effects of Domestic Waste Water on Water Quality of Three Reservoirs Supplying Drinking Water in Kaduna State - Northern Nigeria
}

\author{
Yahuza Tanimu, Sunday Paul Bako and John Ameh Adakole \\ Department of Biological Sciences, \\ Ahmadu Bello University, \\ Nigeria
}

\section{Introduction}

Waste water management in Nigeria does not receive the attention it deserves. Domestic waste water is discharged into streams and reservoirs that supply drinking water without any treatment (Tiseer et al., 2008). Chemical substances from agricultural activities (fertilizers, pesticides and herbicides) in the catchment of reservoirs may introduce nutrients and heavy metals at concentrations higher than that which the environment can handle (WHO, 2006). Nigeria has a number of environmental regulatory laws which include: the National Environmental Standards and Regulations Enforcement Agency (Establishment) Act of 2007 (The NESREA Act), Nigerian Radioactive Waste Management Regulations 2006, Environmental Impact Assessment Act of 1992 (EIA Act), Harmful Wastes (Special Criminal Provisions etc.) Act of 1988 (Harmful Wastes Act), the National Oil Spill Detection and Response Agency (Establishment) Act 2006 (the NOSDRA Act) and Nigerian Radioactive Waste Management Regulations 2006. However, the enforcement of these regulations has not been effective (Onaruwa and Fakayode, 2002 and Adegoroye, 2008) and thus pollution of both rural and urban water sources commonly occurs. In rural areas, natural sources of drinking water, such as streams, wells and other reservoirs are usually polluted by organic substances from upstream users who use water for Agricultural activities and other domestic purposes. In urban areas, population pressure, industrial activities and agricultural activities place pollution stress on reservoirs of water (Adakole et al., 2002, Fakayode, 2005 Kimura, 2005, Tiseer et al., 2008). The water in these reservoirs is sometimes taken directly without any form of treatment.

Contamination of sources of water by waste alters water quality (the physical, chemical and biological characteristics). When the physical and chemical conditions of ecosystems are changed beyond their normal ranges, changes may be expected to occur in individual organisms, populations and communities of the ecosystem (Lenat et al., 1980, Akin-Oriola, 2003, Kadiri, 2006). Assemblages of cyanobacteria are good indicators of eutrophic water bodies (Reynolds, 1998). Some species of cyanobacteria could contain cyanotoxins in their cells but do not release these into the water, and as such are harmful only when consumed while others release toxins directly into the water (Chorus and Batram, 1999 and WHO, 2006). They can also alter taste and odor problems, cause water discoloration, or form large 
mats that can intefere with boating, swimming, and fishing (Borgh, 2004). Cyanobacteria present a range of characteristics that give them clear competitive growth advantage over planktonic algae under certain environmental conditions. Such include; a requirement of low light intensity and little energy to maintain cell structure and function (Mur et al., 1999); possession of gas vacuoles within their cells as a buoyancy regulation mechanism to avoid light damage in high-light environments, such as in tropic lakes or to access light in turbid or low-clarity water (Haider et al., 2003). Cyanobacteria can also store phosphorus (luxury uptake), as a useful adaptation that allows continued growth under conditions of fluctuating nutrient concentrations. They are also not grazed by zooplankton, since they are not the preferred food for these aquatic organisms (Chorus and Batram, 1999).

Data on levels of aquatic pollution and its implication to human health is generally lacking for most aquatic ecosystems in Nigeria. This study was therefore designed to evaluate the impact of waste water on three reservoirs receiving varying degrees of waste water.

\section{Materials and methods}

\subsection{Study area}

The three reservoirs studied were Gimbawa reservoir in Ikara Local Govt. (Long. $10^{\circ} 6^{\prime} \mathrm{N}$ and Lat.8035'E), Saminaka reservoir in Lere Local Govt. (10॰70' $\mathrm{N}$ and $\left.8^{\circ} 75^{\prime} \mathrm{E}\right)$ and Zaria reservoir, Zaria Local Government $\left(7^{0} 38^{\prime} \mathrm{N}\right.$ and $\left.11^{01} 1^{\prime} \mathrm{E}\right)$ of Kaduna State. Kaduna State is located in the northern guinea savannah vegetative zone of Nigeria and has a tropical continental climate, with distinct wet and dry seasons. Three sampling stations were studied in each reservoir based on the diffrent activities in the catchment from May 2008 to April 2009.

\subsection{Phytoplankton collection:}

Phytoplankton was collected using a conical shape plankton net of $20 \mathrm{~cm}$ diameter with a 50 $\mathrm{ml}$ collection vial attached to it (Perry, 2003). Samples were collected at three sampling points in each reservoir to reflect the various activities in the catchment. Phytoplankton was identified by consulting texts by Presscott (1977) and Perry (2003).

\subsection{Physico-chemical parameters}

Physico-chemical parameters of water were analyzed once a month from May 2008 to April 2009. Surface water temperature was measured in situ using a mercury thermometer. $\mathrm{pH}$ and Electrical Conductivity were measured using HANNA instrument ( $\mathrm{pH} /$ Electrical Conductivity/Temperature meter model 210). Total Hardness, Dissolved oxygen (DO), Biological Oxygen Demand (BOD), Nitrate-Nitrogen $\left(\mathrm{NO}_{3}-\mathrm{N}\right)$ and Phosphate-phosphorus $\left(\mathrm{PO}_{4}-\mathrm{P}\right)$ were determined by methods described by APHA (1998).

\subsection{Metal analysis}

Metal concentration in the water samples was determined by Atomic Absorption Spectrophometry (AAS). Water samples were digested by Nitric acid $\left(\mathrm{HNO}_{3}\right)$ digestion (as described by APHA, 1998).

\section{Statistical analysis}

Analysis Of Variance (ANOVA) was used to compare the means of physicochemical parameters; heavy metals concentration and abundance of phytoplankton from the different 
reservoirs. Pearson's correlation coefficient was used to determine the relationship between physicochemical parameteres; physicochemical parametres and phytoplakton. ShannonWiener diversity index was used to determine phytoplankton diversity while Simpson's Index was used to determine evenness of phytoplankton distribution.

\section{Results}

Mean monthly Air Temperature varied from 27.67 to $34.17^{\circ} \mathrm{C}$ with mean \pm standard error of $31.76 \pm 0.62^{\circ} \mathrm{C}$ (Table1), for Gimbawa reservoir, whereas in Saminaka reservoir it ranged between $25^{\circ} \mathrm{C}$ and $36.67^{\circ} \mathrm{C}$ with mean \pm SE of $30.96 \pm 0.97{ }^{\circ} \mathrm{C}$. In Zaria reservoir, air temperature ranged from 26 to $35.33^{\circ} \mathrm{C}$ mean $\pm \mathrm{SE}$ of $29.67 \pm 0.688^{\circ} \mathrm{C}$ (Table 1$)$. This observed difference was however not statistically significant.

The three reservoirs had mean \pm SE of Surface water temperature was $26.16 \pm 1.00{ }^{\circ} \mathrm{C}$ (Gimbawa), $26.19 \pm 1.07{ }^{\circ} \mathrm{C}$ (Saminaka) and $26.08 \pm 0.63{ }^{\circ} \mathrm{C}$ (Zaria) (Table 1). The differences were however, not statistically significant between months, seasons and reservoirs $(\mathrm{P}>0.05)$.

\begin{tabular}{|c|c|c|c|c|c|c|c|c|c|}
\hline & \multicolumn{3}{|c|}{ Gimbawa } & \multicolumn{3}{|c|}{ Saminaka } & \multicolumn{3}{|l|}{ Zaria } \\
\hline & Min & Max & Mean \pm SE & Min & $\operatorname{Max}$ & Mean \pm SE & Min & $\operatorname{Max}$ & Mean $\pm S E$ \\
\hline Air & & & & & & & & & \\
\hline $\begin{array}{l}\text { Temperature } \\
\left({ }^{\circ} \mathrm{C}\right)\end{array}$ & 27.67 & 34.67 & $31.76 \pm 0.62$ & 25 & 36.67 & $30.96 \pm 0.97$ & 26 & 35.33 & $29.67 \pm 0.68$ \\
\hline Water & & & & & & & & & \\
\hline $\begin{array}{l}\text { Temperature } \\
\left({ }^{\circ} \mathrm{C}\right)\end{array}$ & 20.33 & 31.67 & $26.16 \pm 1.00$ & 20 & 31 & $26.19 \pm 1.07$ & 20.67 & 28 & $26.08 \pm 0.63$ \\
\hline Secchi disc & & & & & & & & & \\
\hline $\begin{array}{l}\text { Transparency } \\
\text { (cm) }\end{array}$ & 13.67 & 69.67 & $17.67 \pm 6.06$ & 8.17 & 19.33 & $7.29 \pm 2.19$ & 13.67 & 47 & $21.48 \pm 4.46$ \\
\hline $\begin{array}{l}\mathrm{pH} \\
\text { Electrical }\end{array}$ & 6.87 & 8.76 & $7.54 \pm 0.15$ & 6.46 & 8.21 & $7.34 \pm 0.15$ & 6.42 & 7.9 & $7.31 \pm 0.14$ \\
\hline $\begin{array}{l}\text { Conductivity } \\
(\mu \mathrm{S} / \mathrm{cm})\end{array}$ & 45.1 & 573.33 & $120.50 \pm 41.95$ & 12.33 & 496 & $128.07 \pm 40.00$ & 31.67 & 518 & $97.20 \pm 38.59$ \\
\hline Dissolved & & & & & & & & & \\
\hline $\begin{array}{l}\text { Oxygen } \\
(\mathrm{Mg} / \mathrm{L})\end{array}$ & 6.87 & 8.76 & $6.71 \pm 0.39$ & 3.52 & 9.1 & $6.16 \pm 0.53$ & 3.73 & 10.22 & $6.44 \pm 0.58$ \\
\hline $\begin{array}{l}\text { BOD } \\
(\mathrm{Mg} / \mathrm{L})\end{array}$ & 0.16 & 4.37 & $2.17 \pm 0.41$ & 0.37 & 5.57 & $2.60 \pm 0.5$ & 0.06 & 3.54 & $1.68 \pm 0.38$ \\
\hline $\begin{array}{l}\text { Alkalinity } \\
(\mathrm{Mg} / \mathrm{L})\end{array}$ & 2.87 & 6.7 & $5.05 \pm 0.32$ & 2.43 & 14.8 & $6.77 \pm 1.16$ & 2.5 & 5.8 & $4.29 \pm 0.31$ \\
\hline $\begin{array}{l}\text { Hardness } \\
(\mathrm{Mg} / \mathrm{L})\end{array}$ & 0.5 & 3.93 & $1.26 \pm 0.26$ & 0.43 & 4.53 & $1.46 \pm 0.30$ & 0.6 & 5.1 & \\
\hline $\begin{array}{l}\mathrm{NO}_{3}-\mathrm{N} \\
(\mathrm{Mg} / \mathrm{L})\end{array}$ & 0.03 & 0.19 & $0.12 \pm 0.01$ & 0.02 & 0.16 & $0.09 \pm 0.01$ & 0.01 & 0.55 & $0.13 \pm 0.05$ \\
\hline $\begin{array}{l}\mathrm{P0}_{4}-\mathrm{P} \\
(\mathrm{Mg} / \mathrm{L})\end{array}$ & 0.06 & 0.62 & $0.29 \pm 0.06$ & 0.06 & 0.76 & $0.39 \pm 0.08$ & 0.03 & 0.8 & $0.39 \pm 0.08$ \\
\hline
\end{tabular}

$\mathrm{SE}=$ Standard Error, $\mathrm{BOD}=$ Biochemical Oxygen Demand, $\mathrm{NO}_{3}-\mathrm{N}=$ Nitrate-Nitrogen, $\mathrm{P} 0_{4}-\mathrm{P}=$ Phosphate-phosphorus

Table 1. Physico-chemical characteristics of Gimbawa, Saminaka and Zaria reservoirs 
Secchi Disc Transparency values in Gimbawa reservoir had the highest value of $69.67 \mathrm{~cm}$ and lowest of $13.67 \mathrm{~cm}$. In Saminaka reservoir, the values ranged from 4.36 to $19.33 \mathrm{~cm}$, while in the Zaria reservoir it ranged from 13.67 to $47 \mathrm{~cm}$. The mean \pm Standard Error of the reservoirs are Gimbawa: $17.67 \pm 6.06 \mathrm{~cm}$, Saminaka: $7.29 \pm 2.19 \mathrm{~cm}$ and Zaria: $21.48 \pm 4.46 \mathrm{~cm}$ (Table 1). This observed difference was statistically significant between reservoirs $(\mathrm{P}<0.05)$ and between seasons $(\mathrm{P}<0.05)$.

$\mathrm{pH}$ values in Gimbawa reservoir varied from 6.87 to 8.76. In Saminaka reservoir, the highest $\mathrm{pH}$ value was 8.21 and lowest was 6.46. While in Zaria reservoir, the highest $\mathrm{pH}$ value was 7.9 and lowest of 6.42 . The mean \pm SE observed in the reservoirs were: Gimbawa, 7.54 \pm 0.15 ; Saminaka, 7.44 \pm 0.15 and Zaria, 7.31 \pm 0.14 (Table 1). The observed differences were not significant between reservoirs $(P>0.05)$ but significant between months $(P<0.05)$ and seasons $(\mathrm{P}<0.01)$.

The mean \pm SE Electrical of Conductivity (EC) for Gimbawa, Saminaka and Zaria reservoirs observed were $120.50 \pm 41.95 \mu \mathrm{S} / \mathrm{cm}, 128.07 \pm 40.00 \mu \mathrm{S} / \mathrm{cm}$ and $97.20 \pm 38.59 \mu \mathrm{S} / \mathrm{cm}$ respectively (Table 1). The variation of EC was significant only between months $(\mathrm{P}<0.05)$. Dissolved Oxygen (DO) varied between $8.58 \mathrm{mg} / \mathrm{L}$ and $3.9 \mathrm{mg} / \mathrm{L}$ in Gimbawa reservoir,. Saminaka reservoir had values ranging between $9.1 \mathrm{mg} / \mathrm{L}$ to $3.52 \mathrm{ml} / \mathrm{L}$ while in Zaria reservoir had range of values for DO from $3.73 \mathrm{mg} / \mathrm{L}$ to $10.22 \mathrm{mg} / \mathrm{L}$. The mean $\pm \mathrm{SE}$ of Gimbawa, Saminaka and Zaria reservoirs observed were $6.71 \pm 0.39 \mathrm{mg} / \mathrm{L}, 6.16 \pm 0.53 \mathrm{mg} / \mathrm{L}$ and $6.44 \pm 0.58$ respectively (Table 1 ). The variation of DO was significant between months and seasons $(\mathrm{P}<0.05)$.

Biochemical Oxygen Demand (BOD) values in Gimbawa reservoir ranged from $4.37 \mathrm{mg} / \mathrm{L}$ to $0.16 \mathrm{mg} / \mathrm{L}$, In Saminaka reservoir the values range from 0.37 to $5.57 \mathrm{mg} / \mathrm{L}$ whereas in Zaria reservoir the values ranged from $0.06 \mathrm{mg} / \mathrm{L}$ to $3.54 \mathrm{mg} / \mathrm{L}$. The mean $\pm \mathrm{SE}$ of Gimbawa, Saminaka and Zaria reservoirs observed were $2.17 \pm 0.41 \mathrm{mg} / \mathrm{L}, 2.60 \pm 0.50 \mathrm{mg} / \mathrm{L}$ and $1.68 \pm$ $0.38 \mathrm{mg} / \mathrm{L}$ respectively (Table 1$)$. The variation of BOD was significant between months and seasons $(\mathrm{P}<0.01)$.

The mean \pm SE of Alkalinity for Gimbawa, Saminaka and Zaria reservoirs observed were $5.05 \pm 0.32 \mathrm{mg} / \mathrm{L}, 4.29 \pm 0.31 \mathrm{mg} / \mathrm{L}$ and $6.77 \pm 1.16 \mathrm{mg} / \mathrm{L}$ respectively (Table 1$)$. The variation of Alkalinity was significant between months, reservoirs $(\mathrm{P}<0.05)$ and between seasons $(\mathrm{P}<$ $0.01)$.

The mean \pm SE of Hardness for Gimbawa, Saminaka and Zaria reservoirs observed were $1.26 \pm 0.26 \mathrm{mg} / \mathrm{L}, 1.46 \pm 0.30 \mathrm{mg} / \mathrm{L}$ and $1.49 \pm 0.36 \mathrm{mg} / \mathrm{L}$ respectively (Table 1 ). These variations however, were only significant between months $(\mathrm{P}<0.05)$ and not between months and seasons $(\mathrm{P}>0.05)$.

Nitrate-nitrogen concentration for Gimbawa reservoir had a highest value of $0.19 \mathrm{mg} / \mathrm{L}$ and lowest of $0.03 \mathrm{mg} / \mathrm{L}$. Saminaka reservoir had a highest value of $0.16 \mathrm{mg} / \mathrm{L}$ and lowest of $0.02 \mathrm{mg} / \mathrm{L}$. Zaria reservoir had its highest value of $0.55 \mathrm{mg} / \mathrm{L}$ and lowest of $0.01 \mathrm{mg} / \mathrm{L}$. The mean \pm SE Nitrate-nitrogen concentration for Gimbawa, Saminaka and Zaria reservoirs observed were of $0.01 \mathrm{mg} / \mathrm{L}, 0.09 \pm 0.05 \mathrm{mg} / \mathrm{L}$ and $0.13 \pm 0.05 \mathrm{mg} / \mathrm{L}$ respectively (Table 1 ). These variations however, were not statistically significant between reservoirs, months and seasons $(\mathrm{P}>0.05)$.

For phosphate-phosphorus concentration, Gimbawa had its highest value of $0.62 \mathrm{mg} / \mathrm{L}$ and lowest of $0.18 \mathrm{mg} / \mathrm{L}$. Saminaka reservoir had the highest concentration of $0.76 \mathrm{mg} / \mathrm{L}$ and lowest of $0.04 \mathrm{mg} / \mathrm{L}$. Zaria reservoir had its highest value of $0.8 \mathrm{mg} / \mathrm{L}$ and lowest $0.04 \mathrm{mg} / \mathrm{L}$. The mean \pm SE of Gimbawa, Saminaka and Zaria reservoirs observed were $0.29 \pm 0.06 \mathrm{mg} / \mathrm{L}$, $0.39 \pm 0.08 \mathrm{mg} / \mathrm{L}$ and $0.39 \pm 0.08 \mathrm{mg} / \mathrm{L}$ respectively (Table 1 ). These variations however, were only significant between months $(\mathrm{P}<0.01)$ but not between reservoirs and seasons $(\mathrm{P}>0.05)$. 


\subsection{Metal ions}

The lowest concentrations of $\mathrm{Cu}, \mathrm{Zn}, \mathrm{Mn}, \mathrm{Fe}$ and $\mathrm{Cr}$ were below detectable limits in the three reservoirs. The highest concentration of $\mathrm{Cu}, \mathrm{Zn}$ and $\mathrm{Cr}$ was recorded in Zaria reservoir $(0.39,0.50$ and $1.10 \mathrm{mg} / \mathrm{L}$ respectively). Gimbawa reservoir had the highest concentration of Mn $(1.01 \mathrm{mg} / \mathrm{L})$ and Fe $(1.14 \mathrm{mg} / \mathrm{L})$. The mean \pm SE of these metals in Gimbawa, Saminaka and Zaria respectively are $\mathrm{Cu}: 0.03 \pm 0.03 \mathrm{mg} / \mathrm{L}, 0.03 \pm 0.02 \mathrm{mg} / \mathrm{L}$ and $0.04 \pm 0.03 \mathrm{mg} / \mathrm{L} ; \mathrm{Zn}$ : $0.03 \pm 0.03 \mathrm{mg} / \mathrm{L}, 0.02 \pm 0.01 \mathrm{mg} / \mathrm{L}$ and $0.04 \pm 0.04 \mathrm{mg} / \mathrm{L} ; \mathrm{Mn}: 0.08 \pm 0.08,0.09 \pm 0.06 \mathrm{mg} / \mathrm{L}$ and $0.06 \pm 0.06 \mathrm{mg} / \mathrm{L} \mathrm{mg} / \mathrm{L}$; Fe: $0.28 \pm 0.1 \mathrm{mg} / \mathrm{L}, 0.89 \pm 0.43 \mathrm{mg} / \mathrm{L}$ and $0.51 \pm 0.28 \mathrm{mg} / \mathrm{L}$ and Cr: $0.43 \pm 0.07 \mathrm{mg} / \mathrm{L}, 0.36 \pm 0.06 \mathrm{mg} / \mathrm{L}$ and $0.34 \pm 0.08$.

Concentrations of Nickel in the three reservoirs showed the highest concentrations of 1.06, 1.0 and $1.17 \mathrm{mg} / \mathrm{L}$; and lowest concentrations of $0.17,0.26$ and $0.17 \mathrm{mg} / \mathrm{L}$ for Gimbawa, Saminaka and Zaria reservoirs respectively (Table 2). The mean \pm Standard Error for the reservoirs were $0.64 \pm 0.08 \mathrm{mg} / \mathrm{L}, 0.62 \pm 0.06 \mathrm{mg} / \mathrm{L}$ and $0.69 \pm 0.10 \mathrm{mg} / \mathrm{L}$ for Gimbawa, Saminaka and Zaria reservoirs respectively (Table 2). These differences were however not significant between reservoirs, months and seasons $(\mathrm{P}>0.05)$.

\begin{tabular}{|c|c|c|c|c|c|c|c|c|c|c|}
\hline & \multicolumn{3}{|c|}{ Gimbawa } & \multicolumn{2}{|c|}{ Saminaka } & \multicolumn{3}{|c|}{ Zaria } & \multicolumn{2}{|r|}{ MPL } \\
\hline & Min & Max & $\begin{array}{l}\text { Mean } \\
\pm S E\end{array}$ & Min & Max & $\begin{array}{l}\text { Mean } \\
\text { SE }\end{array}$ & \pm Min & Max & $\begin{array}{l}\text { Mean } \\
\text { SE } \\
\end{array}$ & \\
\hline $\begin{array}{l}\text { Copper } \\
(\mathrm{mg} / \mathrm{L})\end{array}$ & ND & 0.34 & $\begin{array}{l}0.03 \\
0.03\end{array}$ & $\pm \mathrm{ND}$ & 0.25 & $\begin{array}{l}0.03 \\
0.02\end{array}$ & $\pm \mathrm{ND}$ & 0.39 & $\begin{array}{l}0.04 \\
0.03\end{array}$ & $\pm 2 \mathrm{mg} / \mathrm{L}^{*}$ \\
\hline $\begin{array}{l}\text { Zinc } \\
(\mathrm{mg} / \mathrm{L})\end{array}$ & ND & 0.3 & $\begin{array}{l}0.03 \\
0.03\end{array}$ & $\pm \mathrm{ND}$ & 0.17 & $\begin{array}{l}0.02 \pm \\
0.01\end{array}$ & ND & 0.5 & $\begin{array}{l}0.04 \\
0.04\end{array}$ & $\pm 3 \mathrm{mg} / \mathrm{L}^{*}$ \\
\hline $\begin{array}{l}\text { Manganese } \\
\text { (mg/L) }\end{array}$ & ND & 1.01 & $\begin{array}{l}0.08 \\
\pm 0.08\end{array}$ & ND & 0.58 & $\begin{array}{l}0.09 \\
0.06\end{array}$ & $\pm N D$ & 0.72 & $\begin{array}{l}0.06 \\
0.06\end{array}$ & $\pm 0.5 \mathrm{mg} / \mathrm{L}^{*}$ \\
\hline $\begin{array}{l}\text { Cadmium } \\
(\mathrm{mg} / \mathrm{L})\end{array}$ & 0.06 & 0.22 & $\begin{array}{l}0.14 \pm \\
0.01\end{array}$ & 0.06 & 1.87 & $\begin{array}{l}0.16 \\
0.02\end{array}$ & \pm 0.06 & 0.25 & $\begin{array}{l}0.11 \\
0.02\end{array}$ & $\pm 0.003 \mathrm{mg} / \mathrm{L}^{*}$ \\
\hline $\begin{array}{l}\text { Iron } \\
(\mathrm{mg} / \mathrm{L})\end{array}$ & ND & 1.14 & $\begin{array}{l}0.28 \\
0.1\end{array}$ & $\pm \mathrm{ND}$ & 5.5 & $\begin{array}{l}0.89 \\
0.43\end{array}$ & $\pm \mathrm{ND}$ & 3.55 & $\begin{array}{l}0.51 \\
0.28\end{array}$ & $\pm 0.3 \mathrm{mg} / \mathrm{L}^{*}$ \\
\hline $\begin{array}{l}\text { Nickel } \\
(\mathrm{mg} / \mathrm{L})\end{array}$ & 0.17 & 1.06 & $\begin{array}{l}0.64 \\
0.08\end{array}$ & \pm 0.26 & 1 & $\begin{array}{l}0.62 \\
0.06\end{array}$ & \pm 0.17 & 1.17 & $\begin{array}{l}0.69 \\
0.10\end{array}$ & $\pm 0.02 \mathrm{mg} / \mathrm{L}^{*}$ \\
\hline $\begin{array}{l}\text { Chromium } \\
(\mathrm{mg} / \mathrm{L})\end{array}$ & ND & 0.96 & $\begin{array}{l}0.43 \\
0.07\end{array}$ & $\pm \mathrm{ND}$ & 0.67 & $\begin{array}{l}0.36 \pm \\
0.06\end{array}$ & ND & 1.1 & $\begin{array}{l}0.34 \\
0.08\end{array}$ & $\pm 0.05 \mathrm{mg} / \mathrm{L}^{*}$ \\
\hline $\begin{array}{l}\text { Calcium } \\
(\mathrm{mg} / \mathrm{L})\end{array}$ & 2.33 & 41.67 & $\begin{array}{l}7.70 \\
3.10\end{array}$ & \pm 1 & 20 & $\begin{array}{l}6.4 \\
1.93\end{array}$ & \pm 1 & 40 & $\begin{array}{l}5.6 \\
3.14\end{array}$ & $\pm 200 \mathrm{mg} / \mathrm{L}^{*}$ \\
\hline $\begin{array}{l}\text { Magnesium } \\
(\mathrm{mg} / \mathrm{L})\end{array}$ & 1.6 & 4.7 & $\begin{array}{l}3.01 \\
0.24\end{array}$ & \pm 0.9 & 8.3 & $\begin{array}{l}3.19 \pm \\
0.74\end{array}$ & 0.8 & 5.1 & $\begin{array}{l}2.59 \\
0.31\end{array}$ & $\pm 0.02 \mathrm{mg} / \mathrm{L}^{* *}$ \\
\hline $\begin{array}{l}\text { Potassium } \\
(\mathrm{mg} / \mathrm{L})\end{array}$ & 2.6 & 8.5 & $\begin{array}{l}4.80 \\
0.56\end{array}$ & \pm 2.4 & 9.4 & $\begin{array}{l}4.8 \\
0.55\end{array}$ & \pm 2.8 & 6 & $\begin{array}{l}4.2 \\
0.26\end{array}$ & $\pm 200 \mathrm{mg} / \mathrm{L}^{*}$ \\
\hline $\begin{array}{l}\text { Sodium } \\
(\mathrm{mg} / \mathrm{L})\end{array}$ & 8.9 & 14.5 & $\begin{array}{l}12.19 \\
0.53\end{array}$ & \pm 6.4 & 27.3 & $\begin{array}{l}11.49 \\
1.75\end{array}$ & \pm 6.8 & 15.9 & $\begin{array}{l}9.84 \\
0.74\end{array}$ & $\pm 200 \mathrm{mg} / \mathrm{L}^{*}$ \\
\hline
\end{tabular}

$\mathrm{ND}=$ not detectable, Min= minimum, Max= maximum, SE= Standard Error ${ }^{*}$ WHO, 2006 ** Standard Organisation of Nigeria, 2007, MPL = maximum permissible limit

Table 2. Mean Values of Metal ions Observed in Gimbawa, Saminaka and Zaria reservoirs 
The highest concentrations of 1.01, 0.58 and $0.5 \mathrm{mg} / \mathrm{L}$ of Manganese were observed in Gimbawa, Saminaka and Zaria reservoirs, the lowest concentrations of Manganese were below detectable limits in the three reservoirs. The mean $\pm \mathrm{SE}$ concentration of Manganese was $0.08 \pm 0.08 \mathrm{mg} / \mathrm{L}, 0.09 \pm 0.06 \mathrm{mg} / \mathrm{L}$ and $0.11 \pm 0.06 \mathrm{mg} / \mathrm{L}$ in Gimbawa, Saminaka and Zaria reservoirs respectively (Table 2 ).

The concentrations of Cadmium in the three reservoirs showed highest values of $0.22,0.25$ and $0.19 \mathrm{mg} / \mathrm{L}$ in Gimbawa, Saminaka and Zaria reservoirs respectively. The three reservoirs had lowest concentrations of $0.06 \mathrm{mg} / \mathrm{L}$ during the study period. The mean \pm Standard Error for the reservoirs were $0.14 \pm 0.01 \mathrm{mg} / \mathrm{L}, 0.16 \pm 0.02 \mathrm{mg} / \mathrm{L}$ and $0.11 \pm 0.02$ $\mathrm{mg} / \mathrm{L}$ for Gimbawa, Saminaka and Zaria reservoirs respectively (Table 2). These differences were however not significant between reservoirs, months and seasons $(\mathrm{P}>0.05)$.

Magnesium concentration in the three reservoirs showed a highest concentration of $4.7 \mathrm{mg} / \mathrm{L}, 8.3 \mathrm{mg} / \mathrm{L}$ and $5.1 \mathrm{mg} / \mathrm{L}$ and lowest of 1.6, 0.9 and 0.8 for Gimbawa, Saminaka and Zaria reservoirs respectively. The mean \pm SE for the reservoirs were $7.70 \pm 3.10 \mathrm{mg} / \mathrm{L}, 6.4 \pm$ $1.93 \mathrm{mg} / \mathrm{L}$ and $5.6 \pm 3.14 \mathrm{mg} / \mathrm{L}$ for Gimbawa, Saminaka and Zaria reservoirs respectively (Table 2). These differences were however not significant between reservoirs and months ( $P$ $>0.05)$ but significant between seasons $(\mathrm{P}<0.05)$.

The highest Sodium concentrations observed were 14.5, 27.3 and $15.9 \mathrm{mg} / \mathrm{L}$ and lowest of 8.9, 6.4, and $6.8 \mathrm{mg} / \mathrm{l}$ in Gimbawa, Saminaka and Zaria reservoirs respectively. The mean \pm SE for the reservoirs were $12.19 \pm 0.53 \mathrm{mg} / \mathrm{L}, 11.49 \pm 1.75 \mathrm{mg} / \mathrm{L}$ and $9.84 \pm 0.74 \mathrm{mg} / \mathrm{L}$ for Gimbawa, Saminaka and Zaria reservoirs respectively (Table 2). These differences were however not significant between reservoirs and months $(P>0.05)$ but significant between seasons $(P<0.05)$, with significant interaction between reservoirs and seasons $(P<0.01)$.

Gimbawa, Saminaka and Zaria reservoirs had the highest concentration of Potassium of 8.5, 9.4 and $6 \mathrm{mg} / \mathrm{L}$ and lowest of 2.6, 2.4 and $2.8 \mathrm{mg} / \mathrm{L}$ respectively. The mean \pm Standard Error for the reservoirs were $4.80 \pm 0.56 \mathrm{mg} / \mathrm{L}, 4.80 \pm 0.53 \mathrm{mg} / \mathrm{L}$ and $4.2 \pm 0.26 \mathrm{mg} / \mathrm{L}$ for Gimbawa, Saminaka and Zaria reservoirs respectively (Table 2). These differences were however not significant between reservoirs, months and seasons $(\mathrm{P}>0.05)$.

The three reservoirs had the highest Iron concentrations of $1.14 \mathrm{mg} / \mathrm{L}$ (Gimbawa), $5.4 \mathrm{mg} / \mathrm{L}$ (Saminaka) and $3.55 \mathrm{mg} / \mathrm{L}$ (Zaria). The lowest concentrations of Iron were below detectable limits in the three reservoirs. The mean \pm Standard Error for the reservoirs were $0.28 \pm 0.1$ $\mathrm{mg} / \mathrm{L}, 0.89 \pm 0.43 \mathrm{mg} / \mathrm{L}$ and $0.51 \pm 0.28 \mathrm{mg} / \mathrm{L}$ for Gimbawa, Saminaka and Zaria reservoirs respectively (Table 2). These differences were however not significant between reservoirs, months and seasons $(\mathrm{P}>0.05)$.

\subsection{Cyanobacteria}

Gimbawa reservoir had its highest number of cyanobacteria cells/L in the month of December (112) and lowest in the month June and August (0 cells/L). Saminaka reservoir had its highest number in the month of March (292 cells/L) and lowest in the months of June and January

(4cells/L). Zaria reservoir had its highest abundance in October (88cells/L) and lowest in the month of May (32 cells/L) (Table 3).

Number of taxa (8), number of individuals (308), Shannon Index (1.59) and Simpson index (0.76) was observed in Gimbawa reservoir during the dry season was higher than that observed in the wet season $(4,152,1.11$ and 0.62 respectively). Dominance was higher in the wet season (0.38) than dry season (0.24). 
\begin{tabular}{llllllllll}
\hline Reservoir & May Jun Jul Aug & Sep Oct & Nov Dec Jan & Feb & Mar & Apr & Total
\end{tabular}

\begin{tabular}{llllllllllllll}
\hline Gimbawa & 16 & 0 & 28 & 0 & 68 & 12 & 60 & 112 & 12 & 40 & 40 & 44 & 432 \\
Saminaka & 24 & 12 & 40 & 32 & 60 & 40 & 48 & 52 & 4 & 68 & 292 & 220 & 892 \\
Zaria & 32 & 68 & 36 & 36 & 88 & 188 & 120 & 76 & 68 & 76 & 48 & 4 & 840 \\
\hline
\end{tabular}

Table 3. Monthly Abundance (cells/L) of Cyanobacteria in Gimbawa, Saminaka and Zaria reservoirs

In Saminaka reservoir the trend was similar, number of individuals (464), Shannon Index (0.97) and Simpson index (0.56) observed during the dry season was higher than that observed in the wet season (236, 0.81 and 0.41 respectively), dominance was higher in the wet season (0.38) than dry season (0.24). The only exception was that the number of taxa observed in both seasons was equal (5).

\begin{tabular}{|c|c|c|c|c|c|c|}
\hline Diversity Index & Gimbawa & & Saminaka & & Zaria & \\
\hline & Wet & Dry & Wet & Dry & Wet & Dry \\
\hline Taxa_S & 4 & 8 & 5 & 5 & 4 & 6 \\
\hline Individuals & 152 & 308 & 236 & 464 & 448 & 392 \\
\hline Dominance_D & 0.38 & 0.24 & 0.59 & 0.44 & 0.53 & 0.31 \\
\hline Shannon_H & 1.11 & 1.59 & 0.81 & 0.97 & 0.88 & 1.38 \\
\hline Simpson_1-D & 0.62 & 0.76 & 0.41 & 0.56 & 0.47 & 0.69 \\
\hline
\end{tabular}

Table 4. Seasonal Diversity Indices of Cyanobacteria in Gimbawa, Saminaka and Zaria reservoirs

In Zaria reservoir, the dry season a higher number of taxa (6), Shannon index (1.4) and Simpson index ( 0.69$)$ were observed than the wet season ( $4,0.88$ and 0.47 respectively). While dominance (0.53) and number of individuals (448) observed in the wet season were higher than that observed in the dry season (0.31 and 392 respectively) (Table 4 ).

\subsection{Relationship between physico-chemical characteristics and phytoplankton}

In Gimbawa reservoir significant positive correlation was observed between $\mathrm{Mg}$ and Sacconema sp $(\mathrm{r}=0.43)$ and Trichodesmium sp $(\mathrm{r}=0.43)$ and between Fe and Arthrospira sp (0.43) and Borzia sp (0.43) (Table 5). $\mathrm{pH}$ and Electrical Conductivity showed significant positive correlation with Arthrospira sp (0.75 and 0.98 respectively); Borzia sp (0.75 and 0.98 
respectively) and Merismopedia sp (0.51 and 0.64 respectively); BOD with Merismopedia sp (0.55) (Table 6).

In Saminaka reservoir, significant positive correlation was observed between Chromium with Oscillatoria sp $(\mathrm{r}=0.40)$; Nickel with Gleocystis sp $(\mathrm{r}=0.63)$, Microcystis sp $(0.67)$ and Trichodesmium sp (0.45); Cadmium with Gleocystis $\mathrm{sp}(\mathrm{r}=0.82)$, Microcystis $\mathrm{sp}(0.88)$ and Iron with Microcystis sp (0.66). Significant negative correlation was observed between Potassium and Spirulina sp (-0.45); Sodium with Oscillatoria sp (-0.48) and Sacconema sp (-0.64); Chromium with Merismopedia sp (-0.49) (Table 5). Microcystis sp was observed to show significant positive correlation with DO (0.42), BOD (0.49), Alkalinity (0.64), $\mathrm{NO}_{3}-\mathrm{N}(0.45)$. It showed significant negative correlation with Transparency $(-0.40)$ and $\mathrm{PO}_{4}-\mathrm{P}(-0.54)$. Oscillatoria sp showed significant positive correlation with Air Temperature (0.53), DO (0.50) and Alkalinity (0.50). Spirulina sp showed significant positive correlation with BOD (0.52) (Table 6).

\begin{tabular}{|c|c|c|c|c|c|c|c|}
\hline & $\mathbf{K}$ & $\mathrm{Na}$ & Mg & $\mathrm{Cr}$ & $\mathrm{Ni}$ & $\mathrm{Cd}$ & Fe \\
\hline \multicolumn{8}{|l|}{ Gimbawa } \\
\hline Arthrospira sp & 0.13 & -0.12 & 0.04 & -0.13 & 0.07 & 0.36 & $0.43^{*}$ \\
\hline Borzia sp & 0.13 & -0.12 & 0.04 & -0.13 & 0.07 & 0.36 & $0.43^{*}$ \\
\hline Merismopedia sp & -0.09 & 0.11 & -0.09 & 0.15 & -0.06 & 0.1 & 0.24 \\
\hline Oscillatoria sp & -0.35 & 0.23 & -0.15 & 0.18 & -0.3 & -0.22 & 0.04 \\
\hline Sacconema sp & 0.01 & -0.12 & $0.43^{*}$ & 0.1 & -0.08 & 0.12 & -0.11 \\
\hline Spirulina sp & 0.34 & -0.18 & -0.06 & -0.39 & 0.14 & 0.26 & 0.17 \\
\hline Spondylosium sp & -0.36 & -0.3 & -0.04 & -0.3 & 0.29 & 0.25 & -0.23 \\
\hline Trichodesmium $\mathrm{sp}$ & 0.01 & -0.12 & $0.43^{*}$ & 0.1 & -0.08 & 0.12 & -0.11 \\
\hline \multicolumn{8}{|l|}{ Saminaka } \\
\hline Gleocystis sp & -0.19 & 0.02 & 0.08 & 0.24 & $0.63^{* *}$ & $0.82^{* *}$ & 0.76 \\
\hline Merismopedia sp & 0.11 & $0.55^{*}$ & 0.33 & $-0.49^{*}$ & 0.07 & 0.04 & 0.12 \\
\hline Microcystis sp & -0.24 & -0.17 & 0.10 & 0.13 & $0.67^{* *}$ & $0.88^{* *}$ & $0.66^{* *}$ \\
\hline Nostoc sp & 0.12 & 0.26 & 0.02 & -0.18 & 0.05 & -0.05 & -0.02 \\
\hline Oscillatoria sp & -0.11 & $-0.48^{*}$ & -0.31 & $0.40^{*}$ & 0.19 & -0.22 & 0.29 \\
\hline Rivularia sp & -0.04 & 0.20 & -0.18 & -0.31 & -0.27 & -0.25 & 0.02 \\
\hline Saccconema sp & 0.35 & $-0.64^{*}$ & 0.34 & 0.01 & -0.32 & -0.19 & -0.21 \\
\hline Spirulina sp & $-0.45^{*}$ & -0.33 & -0.08 & -0.12 & -0.31 & -0.10 & -0.26 \\
\hline Spondilosium sp & 0.13 & 0.28 & 0.06 & -0.01 & 0.28 & 0.30 & -0.16 \\
\hline Trichodesmium sp & 0.27 & 0.09 & -0.04 & -0.01 & $0.45^{*}$ & 0.08 & -0.01 \\
\hline \multicolumn{8}{|l|}{ Zaria } \\
\hline Merismopedia sp & -0.38 & -0.02 & -0.14 & -0.20 & -0.18 & -0.31 & -0.16 \\
\hline Nostoc sp & 0.12 & 0.26 & 0.02 & -0.18 & 0.05 & -0.05 & -0.02 \\
\hline Oscillatoria sp & -0.11 & $-0.48^{* *}$ & -0.31 & $0.40^{*}$ & 0.19 & -0.22 & 0.29 \\
\hline Sacconema sp & $-0.49^{*}$ & 0.03 & -0.15 & -0.18 & 0.05 & -0.01 & -0.21 \\
\hline Spirulina sp & $-0.45^{*}$ & -0.33 & -0.08 & -0.12 & -0.31 & -0.10 & -0.26 \\
\hline Spondilosium sp & 0.13 & 0.28 & 0.06 & -0.01 & 0.28 & 0.30 & -0.16 \\
\hline Trichodesmium sp & 0.27 & 0.09 & -0.04 & -0.01 & 0.45 & 0.08 & -0.01 \\
\hline
\end{tabular}

*Significant $\mathrm{P}<0.05,{ }^{* *}$ Significant $\mathrm{P}<0.05$

Table 5. Correlation Coefficient ( $\mathrm{r}$ ) between Cyanobacteria and Metal Ion Concentration in Gimbawa, Saminaka and Zaria reservoirs 
In Zaria reservoir, Significant negative correlation was observed between Potassium and Sacconema sp $(\mathrm{r}=-0.49)$, Spirulina $\mathrm{sp}(\mathrm{r}=-0.45)$; Sodium with Oscillatoria $\mathrm{sp}(\mathrm{r}=-0.48)$. Chromium showed significant positive correlation with Oscillatoria sp (0.40) (Table 5).

\begin{tabular}{|c|c|c|c|c|c|c|c|c|c|c|c|}
\hline Species & $\begin{array}{l}\text { Air } \\
\text { Temp }\end{array}$ & $\begin{array}{l}\text { Water } \\
\text { Temp }\end{array}$ & Transp & $\mathrm{pH}$ & EC & DO & BOD & Alkalinity & Hardness & $\mathrm{NO}_{3}-\mathrm{N}$ & $\mathrm{PO}_{4}-\mathrm{P}$ \\
\hline \multicolumn{12}{|l|}{ Gimbawa } \\
\hline $\begin{array}{l}\text { Arthrospira } \\
\mathrm{sp}\end{array}$ & 0.08 & 0.32 & -0.26 & $0.75^{*}$ & $0.98^{* *}$ & 0.25 & 0.25 & 0.27 & -0.11 & -0.04 & 0.22 \\
\hline $\begin{array}{l}\text { Borzia } \\
\mathrm{sp}\end{array}$ & 0.08 & 0.32 & -0.26 & $0.75^{*}$ & $0.98^{* *}$ & 0.25 & 0.25 & 0.27 & -0.11 & -0.04 & 0.22 \\
\hline $\begin{array}{l}\text { Merismopedia } \\
\text { sp } \\
\text { Saminaka }\end{array}$ & 0.31 & 0.33 & 0.02 & $0.51^{*}$ & $0.64^{* *}$ & 0.32 & $0.55^{* *}$ & 0.04 & 0.00 & -0.07 & 0.23 \\
\hline $\begin{array}{l}\text { Microcystis } \\
\mathrm{sp}\end{array}$ & 0.13 & 0.08 & $-0.40^{*}$ & 0.37 & 0.34 & $0.42^{*}$ & $0.49^{*}$ & $0.64^{* *}$ & 0.03 & $0.45^{*}$ & $-0.54^{* *}$ \\
\hline $\begin{array}{l}\text { Oscillatoria } \\
\mathrm{sp}\end{array}$ & $0.53^{* *}$ & 0.18 & 0.35 & 0.29 & 0.12 & $0.50^{* *}$ & 0.27 & $0.50^{* *}$ & -0.15 & 0.14 & 0.15 \\
\hline $\begin{array}{l}\text { Spirulina } \\
\text { sp } \\
\text { Zaria }\end{array}$ & 0.14 & 0.39 & -0.06 & 0.22 & 0.05 & 0.08 & $0.52^{* *}$ & 0.28 & -0.12 & 0.26 & -0.01 \\
\hline $\begin{array}{l}\text { Nostoc } \\
\mathrm{sp}\end{array}$ & $-0.50^{* *}$ & $-0.80^{* *}$ & $0.62^{* *}$ & 0.36 & -0.15 & 0.11 & 0.02 & 0.14 & 0.00 & -0.01 & -0.39 \\
\hline $\begin{array}{l}\text { Spirulina } \\
\text { sp }\end{array}$ & 0.14 & 0.24 & -0.22 & -0.29 & -0.20 & 0.00 & 0.01 & -0.15 & -0.28 & -0.09 & $0.48^{*}$ \\
\hline $\begin{array}{l}\text { Spondilosium } \\
\text { sp }\end{array}$ & $0.76^{* *}$ & 0.23 & -0.02 & 0.20 & -0.06 & $0.59^{* *}$ & $0.44^{*}$ & $0.45^{*}$ & -0.22 & 0.02 & 0.19 \\
\hline
\end{tabular}

*Significant $\mathrm{P}<0.05$, **Significant $\mathrm{P}<0.05$

Table 6. Correlation Coefficient between Cyanobacteria and Physico-chemical Parameters in Gimbawa, Saminaka and Zaria reservoirs

\section{Discussion}

The statistically significant monthly variation of mean Air Temperature in the three reservoirs could be attributed to the low temperatures experienced between the months of November and February as a result of the harmattan wind (Ezra and Nwankwo, 2001). The significantly higher Transparency of the water in Gimbawa reservoir may be attributed to the low human pressure in its catchment as it is location in the outskirts of a major human settlement. Thus, receiving low amount of silt and nutrients that stimulate algal and cyanobacterial growth. Silt and plankton abundance have been implicated in Transparency fluctuations (Davies et al, 2009). The circum-neutral mean $\mathrm{pH}$ of water in the reservoirs may be attributed to the relatively high alkalinity values of the reservoirs, which is effective as a buffer to fluctuations of $\mathrm{pH}$ that might be caused by introduction of waste water, photosynthesis and other metabolic processes. The wide fluctuations of EC (SE in the range of 38.59 to 41.95) an significantly monthly variations in the three 
reservoirs may be attributed to concentration of Electrical Conducting ions due to evaporation during the extensive (six) months of dry season. Similar results were obtained by Chia and Bako (2008). DO concentration was found within the limit of 5-9 $\mathrm{mg} / \mathrm{l}$, drinking water (UNESCO/WHO/UNEP, 1996). The mean BOD values of Gimbawa and Saminaka were slightly above the $2 \mathrm{mg} / \mathrm{l}$. BOD above $2 \mathrm{mg} / 1$ is associated with waste water contamination (UNESCO/WHO/UNEP, 1996). The mean hardness values $(<1.5$ $\mathrm{mg} / \mathrm{l}$ ) may be due to the uptake of the ions (calcium and magnesium) responsible for harness of water by aquatic organisms. Calcium and Magnesium are essential for aquatic organisms such as algae, cyanobacteria, aquatic macrophytes as well as other reptiles. The Mean $\mathrm{NO}_{3}-\mathrm{N}$ (1.2 and $1.3 \mathrm{mg} / 1$ in Gimbawa and Zaria reservoirs) and $\mathrm{PO}_{4}-\mathrm{P}(0.29$ in Gimbawa reservoir and 0.39 in Saminaka and Zaria reservoirs) were found to be above expected concentration range of natural unpolluted waters of $0.1 \mathrm{mg} / 1$ and $0.001 \mathrm{mg} / 1$ respectively, and are capable of stimulating cyanobacterial bloom (UNESCO/WHO/UNEP, 1996).

Metal ions such as Manganese, Iron, Cadmium, Nickel, Chromium, Magnesium showed concentrations higher than the maximum permissible limit for WHO (2006) and SON (2007), other metals like Copper, Zinc, Sodium and Potassium were found to be below the maximum permissible limit. The implication of high concentrations of metal ions in drinking water include: Manganese causes neurological disorder and at concentrations exceeding $0.1 \mathrm{mg} / \mathrm{L}$ it causes undesirable taste in beverages, stains laundry and may lead to the accumulation of deposit in water distribution system. Iron at levels above $0.3 \mathrm{mg} / \mathrm{L}$ stains laundry and plumbing fixtures (WHO, 2006). Cadmium is toxic to the kidney, Chromium is carcinogenic, and Magnesium affects consumer acceptability of drinking water (SON, 2007). Zinc imparts an undesirable astringent taste to water at threshold concentration of $4 \mathrm{mg} / \mathrm{L}$, water containing Zinc at excess of 3-5mg/L may appear apalacent and develop greasy film on boiling (WHO, 2006). With the exception of Magnesium, all the others are heavy metals capable of accumulating in increasing concentration as they move up the food chain (Chindah et al, 2004).

The dynamics of the concentration of these metals may be attributed to inflow of waste water from residential areas (as they are components of many household products such as pesticides, fungicides, paints, batteries and plumbing facilities), remobilization from sediment due to fluctuations of $\mathrm{pH}$, inflow of agro-chemicals such as fertilizers, pesticides and herbicides from farms in the catchment of the reservoirs, chemicals from washing of automobiles. Changes in $\mathrm{pH}$ affects the solubility of metal ions, lowering of $\mathrm{pH}$ may remobilize insoluble metal complexes adsorbed on clay and silica in the sediments into the water column, for example at $\mathrm{pH}$ 6.7, Zinc is available to form complexes with organic matter while at $\mathrm{pH}>7$ Zinc begin to hydrolyze and form stable $\mathrm{Zn}(\mathrm{OH})_{2}$ at $\mathrm{pH}$. It is important to note that there is a difference between the presence of a metal and its bioavailability. A metal may be present in a form that is not available for utilization by algae and other organisms (Kalis, 2006).

The variation in abundance of Cyanobacteria (Saminaka > Zaria > Gimbawa) in the reservoirs during the study period may be attributed to the variation in $\mathrm{N}$ : $\mathrm{P}$ ratio (Gimbawa, 0.41; Saminaka, 0.23 and Zaria, 0.33) of the water bodies. Lower N: P ratio promotes cyanobacteria abundance (Tisser et al., 2008). They take advantage of their ability 
to fix nitrogen into the aquatic environment, thus enabling them to out-compete other divisions (Chorus and Batram, 1999). High phosphate concentration may result from detergents from sewage, washing of cars, clothes and from fertilization of farms in the catchment of the reservoirs (Reynolds, 1998). High abundance of Cyanobacteria in drinking water may be a serious problem in drinking water as they produce toxins which are harmful to fish, livestock, other aquatic organisms and ultimately man (WHO, 2006). The presence of a bloom of species Microcystis, a toxin producing genus in the Saminaka reservoir is worrisome.

The differences in number of taxa and number of individuals between seasons may be due differences in temperatures and $\mathrm{pH}$ as different species obtain nutrition at different $\mathrm{pH}$ and temperatures. Wilm and Dorris (1966) have suggested a relationship between species diversity and pollution status of aquatic system and classified as follows; $>1=$ Clean water, 1-3 = moderately-polluted $<1=$ Heavily- polluted. Based on this classification, Gimbawa reservoir was moderately polluted in both seasons, Saminaka reservoir heavily polluted in both seasons while the Zaria reservoir was heavily polluted in the wet season and moderately polluted in the dry season. A similar classification was also used by Shehata et. al. (2009). Simpson index gives the evenness of species distribution; the higher evenness in species distribution in the dry season may be an indication that the water quality was better to support the growth of most of the species observed.

Significant positive correlation between cyanobacteria and metal ions may be an indication of the possibility of using as indicators of the levels of these metals in a water body. These metals are either essential ( $\mathrm{Fe}, \mathrm{Cu}, \mathrm{Zn}, \mathrm{Na}, \mathrm{Ca}, \mathrm{Mn}, \mathrm{Co}$ and $\mathrm{K}$ ) or beneficial ( $\mathrm{Ni}$ and $\mathrm{As}$ ) in phytoplankton physiological processes (Paerles-Vela, et al., 2006). Significant negative correlation between metal ions and cyanobacteria may be an indication of toxicity of these metals at high concentrations level exceeding the requirement for nutrition or increased utilization of metals in periods of high abundance. Some of the metals that show significant negative correlation with cyanobacteria abundance are either essential $(\mathrm{Fe}, \mathrm{Cu}, \mathrm{Zn}, \mathrm{Na}, \mathrm{Ca}$, $\mathrm{Mn}, \mathrm{Co}$ and $\mathrm{K}$ ) or beneficial ( $\mathrm{Ni}$ and $\mathrm{As}$ ) in cyanobacteria physiological processes (Daffus, 2002). Significant negative correlation between metal ions and cyanobacteria may be an indication of toxicity of these metals at high concentrations level exceeding the requirement for nutrition or increased utilization of metals in periods of high abundance ((Paerles-Vela, et al., 2006).

Significant positive correlation between cyanobacteria with $\mathrm{pH}$ and alkalinity may be due to the fact that some essential elements are bioavailable at certain required $\mathrm{pH}$, on the other hand, the bioavailability of certain elements at toxic concentrations as affected by $\mathrm{pH}$ may cause a significant negative correlation between $\mathrm{pH}$ and alkalinity with cyanobacterial abundance. A significant positive correlation between nutrient ( $\mathrm{N}$ and $\mathrm{P}$ ) load and cyanobacteria abundance may be due to the fact that increased nutrient concentrations leads to a resultant increase in cyanobacteria abundance and a significant negative correlation may due to the reason that increased cyanobacteria abundance may lead to increased utilization of such nutrients by cyanobacteria (Rabalais, 2002). The significant relationship(s) between cyanobacteria abundance and DO, BOD, EC, Hardness, Temperature and Transparency is an indication of the inter-dependance between these important water quality characteristics and the Biota (Shehata et al., 2009). 


\section{Conclusion}

The introduction of waste water into these reservoirs greatly impairs the water quality of these reservoirs. The consequence is seen as the elevated concentration of heavy metals such as Cadmium, Iron, Nickel and Chromium above WHO permissible limit in drinking water. Waste water is also implicated in the increased nutrient ( $\mathrm{N}$ and $\mathrm{P}$ ) levels. These nutrients were found to be below concentrations to cause any harm directly to consumers but indirectly by their ability to stimulate cyanobacterial growth. Shannon-Weiner diversity index showed that the water quality of the three reservoirs follows this order Gimbawa > Zaria > Saminaka.

\section{References}

Adakole J.A, Balogun J.K. and Lawal, F.A. (2002). Water Quality Impacts Assessment Associated with an Urban Stream in Zaria, Nigeria. NISEB Journal 2(3): 195-203.

Adegoroye, A. (2008). The Challenges of Environmental Enforcement in Africa: The Nigerian Experience. Proceedings of the Third International Conference of Environmental Enforcement, Pp $43-52$.

Akin-Oriola, G.A. (2003). On the Phytoplankton of Awba reservoir, Ibadan, Nigeria. Revista de Biol. 51: 1-15.

APHA (1998). Standard Methods for the Analysis of Water and Wastewater. American Public Health Association, New York.1287pp.

Borgh, M.V. (2004). http:// h20.enr.state.nc.us/esb/EU.html

Chia, A.M and Bako, S.P. (2008). Seasonal Variation of Cyanobacteria in Relation to Physicochemical Parameters of some Fresh Water Ecosystems in the Nigerian Guinea Savanna. Proceedings of Taal 2007: 12 th World Lake Conference, Published by Ministry of Environment and Forests, India and International Lake Environment Committee Foundation (ILEC). Pp.1383-1387.

Chindah, A.C., Braide, A.S. and Sibendu, O.C. (2004). Distribution of Hydrocarbons and Heavy Metals in Sediment and Cinstaceen (Shrimps-Pannens Notialis) from the Bonny/New Calabar River Eastuary. A JEAM-RAGEE, 9:1-17.

Chorus, I. and Bartram, J. (1999). Toxic Cyanobacteria in Water: a Guide to Public Health Consequence, Monitoring and Management. World Health Organization, London, pp.15-40.

Daffus, J.H. (2002). "Heavy Metals" - A Meaningless Term? Pure Appl. Chem., 74(5):793-807.

Davies, O.A., Abowel, J.F.N. and Tawari, C.C. (2009). Phytoplankton Community of Elechi Creek, Niger Delta Nigeria - A Nutrient-Polluted Tropical Creek. American Journal of Applied Science 6(6):1143-1152.

Ezra, A.G. and Nwankwo (2001). Composition of Phytoplankton Algae in Gubi Reservoir, Bauchi, Nigeria. Journal of Aquatic Science 16(2)115-118.

Fakayode, S.O. (2005). Impact Assessment of Industrial effluent on Water Quality of the Receiving Alaro River in Ibadan, NIgeria, AJEAM-RAGEE: 10:1-13.

Haider, S., Naithani V., Viswanathan, P.N. and Kakkar P. (2003). Cyanobacterial Toxins: A Growing Environmental Concern. Chemosphere, 52:1-21. 
Kadiri, M.O. (2006). Phytoplankton Flora and Physicochemical attributes of some waters in the Eastern Niger-Delta area of Nigeria. Nigerian Journal of Botany, 19(2): 188-200.

Kalis, E.J.J. (2006). Chemical speciation and bioavailability of heavy metals in soil and surface water. Ph.D. thesis Wageningen University, Wageningen, the Netherlands. Pp 142.

Kimura, H. (2005). The Japanese New Law for Preservation of Lake Water Quality. In Order of Proceeding World Lake Conference, Nairobi, Kenya. Pp13.

Lenat, O.E., Smock, L.A. and Penrose, O.L.(1980). Use of Benthic macroinvertebrates as indicators of environmental effect. Douglas L.W. (Ed) Pub. Lexington Books, Toronto, 99.

Mur, L.R., Skurlberg, O.M. and Utkilen, H. (1999). Cyanobacteria in the Environment. In: Sperling, E.V. and Gomes, L.N.L. (2008). Cyanotoxin Generation in Tropical Water Supply reservoir. Proceedings of Taal 2007: 12 th World Lake Conference, Published by Ministry of Environment and Forests, India and International Lake Environment Committee Foundation (ILEC. pp) 451-455.

Onrauwa, P.C and Fakayode, S.O. (2002). Heavy Metals Contamination of Soil and Bioaccumulation in Annex Evacs (Panicun maxima) Around Ikaja Industrial Estate, Lagos, Nigeria. Environmental Geology, 43:45-150.

Perales-Vela, H.V., Pena-Castro, J.M. and Canizares-Villanueva (2006). Heavy Metal detoxification in eukaryotic microalgae. Chemosphere 64: 1-10.

Perry, R. ( 2003). A Guide to the marine plankton of southern California. http://www.msc.ucla.edu/oceanglobe

Prescott, G.W. (1977). The Fresh water Algae. WMC Brown Company Publishers Dubugue, IOWA. P 12.

Rabalais, N.N. (2002). Nitrogen in Aquatic Ecosystems. BioOne, 31: 102-112.

Reynolds C.S (1998). What Factors Influence the Species Composition in Lakes of Different Trophic Status? Hydrobiology, (369/370):11-26.

Shehata, S.A., Badr, S.A., Ali, G.H., Ghazy, M.M., Moawad, A.K., and Wahba, S.Z. (2009). Assessment of Nile Water Quality via Phytoplankton changes and Toxicity Bioassay Test. Journal of Applied Sciences, 5(12): 2083-2095.

SON (2007). Nigerian Standard for Drinking Water Quality. Published by the Standard Organisation of Nigeria, Abuja, Nigeria. Pp 30.

Tiseer, F. A., Tanimu, Y. and Chia, A. M. (2008). Seasonal occurrence of algae and physicochemical parameters of Samaru stream, Zaria, Nigeria. Asian journal of Earth Science $1(1): 31-37$.

UNESCO, WHO,UNEP (1996).Water quality assessment- A guide to the use of biota, sediments and water in environmental mornitoring. E and FN Spon. Cambridge, Great Britain, 609 pp.

Wilm, J.L. and Dorris, T.C.(1966). Species Diversity of Benthic Macroinvertebrates.In: A Stream Receiving Domestic and Oil Refinery Effluents. In: Islam, S.M. Phytoplankton diversity index with reference to mucalinda serovar Bodh-Gaya. Order of proceedings of Taal 2007: 12 th World Lack Conference. Published by Ministry of Environment and Forests, India and International Lake Environment Committee Foundation (ILEC). pp 462-463. 
World Health Organisation(2006). Guidelines for drinking water Quality. (2ed) (addendum to vol.1). Recomendations. WHO Press, Geneva Switzerland. Pp 595. 


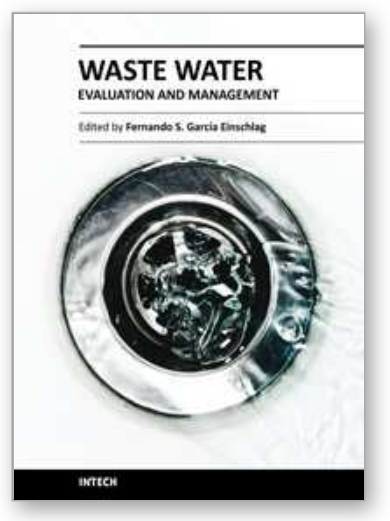

\author{
Waste Water - Evaluation and Management \\ Edited by Prof. Fernando Sebastĩ̃̃in GarcÃa Einschlag
}

ISBN 978-953-307-233-3

Hard cover, 470 pages

Publisher InTech

Published online 01, April, 2011

Published in print edition April, 2011

Fresh water resources are under serious stress throughout the globe. Water supply and water quality degradation are global concerns. Many natural water bodies receive a varied range of waste water from point and/or non point sources. Hence, there is an increasing need for better tools to asses the effects of pollution sources and prevent the contamination of aquatic ecosystems. The book covers a wide spectrum of issues related to waste water monitoring, the evaluation of waste water effect on different natural environments and the management of water resources.

\title{
How to reference
}

In order to correctly reference this scholarly work, feel free to copy and paste the following:

Yahuza Tanimu, Sunday Paul Bako and John Ameh Adakole (2011). Effects of Domestic Waste Water on Water Quality of Three Reservoirs Supplying Drinking Water in Kaduna State - Northern Nigeria, Waste Water - Evaluation and Management, Prof. Fernando SebastiÃ in GarcÃa Einschlag (Ed.), ISBN: 978-953-307-233-3, InTech, Available from: http://www.intechopen.com/books/waste-water-evaluation-and-management/effects-ofdomestic-waste-water-on-water-quality-of-three-reservoirs-supplying-drinking-water-in-kad

\section{INTECH}

open science | open minds

\section{InTech Europe}

University Campus STeP Ri Slavka Krautzeka 83/A 51000 Rijeka, Croatia Phone: +385 (51) 770447 Fax: +385 (51) 686166 www.intechopen.com

\section{InTech China}

Unit 405, Office Block, Hotel Equatorial Shanghai No.65, Yan An Road (West), Shanghai, 200040, China 中国上海市延安西路65号上海国际贵都大饭店办公楼405单元 Phone: +86-21-62489820

Fax: +86-21-62489821 
(C) 2011 The Author(s). Licensee IntechOpen. This chapter is distributed under the terms of the Creative Commons Attribution-NonCommercialShareAlike-3.0 License, which permits use, distribution and reproduction for non-commercial purposes, provided the original is properly cited and derivative works building on this content are distributed under the same license. 